\title{
Dynamic nature of somatic chromosomal mosaicism, genetic-environmental interactions and therapeutic opportunities in disease and aging
}

Svetlana G. Vorsanova ${ }^{1,2}$, Yuri B. Yurov ${ }^{1,2}$ and Ivan Y. lourov ${ }^{1,2,3^{*}}$ (i)

\begin{abstract}
Background: Somatic chromosomal mosaicism is the presence of cell populations differing with respect to the chromosome complements (e.g. normal and abnormal) in an individual. Chromosomal mosaicism is associated with a wide spectrum of disease conditions and aging. Studying somatic genome variations has indicated that amounts of chromosomally abnormal cells are likely to be unstable. As a result, dynamic changes of mosaicism rates occur through ontogeny. Additionally, a correlation between disease severity and mosaicism rates appears to exist. High mosaicism rates are usually associated with severe disease phenotypes, whereas low-level mosaicism is generally observed in milder disease phenotypes or in presumably unaffected individuals. Here, we hypothesize that dynamic nature of somatic chromosomal mosaicism may result from genetic-environmental interactions creating therapeutic opportunities in the associated diseases and aging.

Conclusion: Genetic-environmental interactions seem to contribute to the dynamic nature of somatic mosaicism. Accordingly, an external influence on cellular populations may shift the ratio of karyotypically normal and abnormal cells in favor of an increase in the amount of cells without chromosome rearrangements. Taking into account the role of somatic chromosomal mosaicism in health and disease, we have hypothesized that artificial changing of somatic mosaicism rates may be beneficial in individuals suffering from the associated diseases and/or behavioral or reproductive problems. In addition, such therapeutic procedures might be useful for anti-aging strategies (i.e. possible rejuvenation through a decrease in levels of chromosomal mosaicism) increasing the lifespan. Finally, the hypothesis appears to be applicable to any type of somatic mosacism.
\end{abstract}

Keywords: Aneuploidy, Chromosome, Disease, Environment, Ontogeny, Somatic mosaicism, Therapy

\footnotetext{
* Correspondence: ivan.iourov@gmail.com

'Veltischev Research and Clinical Institute for Pediatrics of the Pirogov

Russian National Research Medical University, Ministry of Health of Russian

Federation, 125412 Moscow, Russia

${ }^{2}$ Mental Health Research Center, 117152 Moscow, Russia

Full list of author information is available at the end of the article
}

(c) The Author(s). 2020 Open Access This article is licensed under a Creative Commons Attribution 4.0 International License, which permits use, sharing, adaptation, distribution and reproduction in any medium or format, as long as you give appropriate credit to the original author(s) and the source, provide a link to the Creative Commons licence, and indicate if changes were made. The images or other third party material in this article are included in the article's Creative Commons licence, unless indicated otherwise in a credit line to the material. If material is not included in the article's Creative Commons licence and your intended use is not permitted by statutory regulation or exceeds the permitted use, you will need to obtain permission directly from the copyright holder. To view a copy of this licence, visit http://creativecommons.org/licenses/by/4.0/. The Creative Commons Public Domain Dedication waiver (http://creativecommons.org/publicdomain/zero/1.0/) applies to the data made available in this article, unless otherwise stated in a credit line to the data. 


\section{$\Pi \alpha \dot{v} v \alpha \chi \omega \rho \varepsilon \quad \kappa \alpha \quad o \quad v \mu \dot{\varepsilon} v \varepsilon \varepsilon$ \\ (Everything flows and nothing stays) \\ Heraclitus of Ephesus}

Somatic chromosomal mosaicism is the presence of chromosomally distinct cellular populations in an individual. This type of intercellular genomic variations is commonly associated with a wide spectrum of genetic diseases ranging from chromosomal syndromes to complex disorders. Furthermore, somatic chromosomal mosaicism is a risk factor for cancer and reproductive problems [1-7]. Increases and decreases in numbers of cells with abnormal karyoptypes are systematically observed in humans through ontogeny (i.e. from zygote to death). The dynamic fluctuations in mosaicism rates have been suggested to be a mechanism for intrauterine control of cell numbers and for aging [8-11]. It is noteworthy that mosaicism rates may change due to genetic-environmental interactions $[12,13]$. Alternatively, mosaic individuals may demonstrate a reversion to normal of inherited mutations $[14,15]$. Moreover, a number of techniques for artificial changing of mosaicism levels appear to exist (e.g. CRISPR/Cas9-mediated genome editing) [16]. Additionally, there is a line of evidences for a kind of self-correction of chromosome abnormalities (decrease of mosaicism rates) in early mammalian development [17-19]. Taking into account these features of somatic mosaicism, we have hypothesized that dynamic changes in rates of chromosomal mosaicism mediated by genetic-environmental interactions are able to deliver therapeutic opportunities in disease and aging.

Almost all types of chromosomal abnormalities (aneuploidy/polyploidy, structural rearrangements, supernumerary marker chromosomes) are able to be mosaic [7, 20-23]. Despite the formation mechanisms (i.e. zygotic or self-correction of chromosomal abnormalities versus post-zygotic or somatic mutagenesis), mosaic chromosomal abnormalities are generally associated with reduced phenotypic penetrance and decreased stability of cellular genomes as compared to regular/non-mosaic ones [3, 7, 10-13, 24, 25]. Somatic chromosomal mosaicism is common in clinical cohorts of patients with neurodevelopmental disabilities and/or congenital anomalies [7, 25-27]. Because of ontogenetic ("ontogenomic") variations, mosaic genome variations causing a wide spectrum of disorders require specific approaches to the diagnosis and management including molecular cytogenetic monitoring of ontogenetic changes in mosaicism rates [28]. Actually, a large amount of data acquired through cytogenetic analyses of mosaicism over the last 50 years has indicated less severe phenotypes of chromosomal disorders to be associated with mosaicism, the rates of which are likely to change ontogenetically.
In early ontogeny, somatic variations of the human genome seem to achieve unprecedently high rates (i.e. the amount of chromosomally abnormal cells achieves the "ontogenetic" maximum). The latter stages are associated with a decrease in chromosomal instability (mosaicism) rates, which still remain high [9, 10, 29, 30]. In parallel, chromosomal mosaicism/instability confines to either extraembryonic or embryonic tissues (i.e. chromosomal mosaicism confined to placenta or fetal brain, respectively) [31-34]. The consequences of these intercellular genomic variations may be devastative at later developmental stages [35, 36]. For instance, high rates of chromosomal mosaicism are associated with $1 / 4$ of spontaneous abortions in the first trimester [3739]. On the other hand, lower rates of chromosomal mosaicism and instability are able to contribute to postnatal morbidity being causative per se or being an element of pathogenic cascades in complex diseases [3, 7, 40]. In the latter scenario (i.e. mosaicism is an element of a pathogenic cascade), chromosomal mosaicism and instability are more likely to result from altered programmed cell death and/or failed cellular selection/ clearance through gestation [9, 10, 33-35]. These alterations seem to be common mechanisms for complex diseases mediated by genetic (chromosomal/genomic) instabilities.

There is a strong evidence that somatic chromosomal mosaicism and instability contributes to the pathogenesis of brain diseases [21, 41-45]. Chromosomal mosaicism has been systematically observed in autistic individuals $[5,7,46,47]$. In schizophrenia, the diseased brain exhibits tissue-specific mosaicism manifested as aneuploidy and specific copy number variations [48-52]. Neurodegeneration has been found to be mediated by somatic aneuploidy and chromosomal instability confined to degenerating brain areas [44, 53-55]. More precisely, Alzheimer's disease has been associated with brain-specific genomic/chromosomal instability (e.g. aneuploidy), which is integrated into the pathogenetic cascade of this devastating disease [56-62]. In addition, molecular (neuro)cytogenetic analyses of this late onset neurodegenerative disease have demonstrated that pathological aging is likely to be mediated by mosaic aneuploidy and chromosome instability in humans [6365]. For more details, see reviews: [12, 21, 41-43, 45, 66]. Behavioral variability and post-traumatic stress disorders are likely to be mediated by genomic/chromosomal instability and somatic mosaicism, as well $[67,68]$. Here, it is important to note that changes of cell proportions are hypothesized to determine the dynamics of behavioral variability (i.e. an increase of abnormal cell numbers may lead to more severe behavioral problems, whereas a decrease of abnormal cell numbers is likely to diminish the severity of behavioral problems) [68]. 
Finally, reproductive problems have long been associated with chromosomal mosaicism, affecting either fetuses or individuals experiencing reproductive failure $[4,9,20$, $22,35-39]$. In total, studying brain diseases in the context of somatic mosaicism suggests that intercellular genetic heterogeneity (chromosomal heterogeneity) is a mechanism for central nervous system dysfunction and the dynamic nature determines the phenotypic outcome. Additionally, empirical and theoretical observations show that a correlation between changes in mosaicism levels and phenotypic manifestations does exist.

Another picturesque example of somatic mosaicism's impact on human homeostasis is aging. Dynamic changes of mosaicism rates produced by the accumulation of somatic mutations (i.e. aneuploidy) seem to be an important cytogenetic mechanism for human aging [69-71]. Cytogenetic and cytogenomic studies of normal and pathological aging consistently demonstrate an increase in rates of chromosomal mosaicism and instability in relation to age $[10,55,63$, 64, 70]. Since 60s, the latest ontogenetic stages have been associated with higher rates of chromosomal mosaicism and instability $[7,8,11]$. Thus, these data allow to hypothesize that external inhibition of agedependent chromosome instability and a decrease of somatic chromosomal mosaicism rates might be an opportunity for anti-aging therapeutic interventions $[10,70]$. Furthermore, somatic cancer-associated mutations commonly occur in aged human tissues of presumably healthy individuals [72]. It is not surprising inasmuch as chromosomal mosaicism and instabilities are risk factors for cancers [73, 74]. In general, aging-related diseases are commonly mediated by chromosomal instability and/or mosaic aneuploidy [7, 41, 44, 45, 55, 75-77]. The results of molecular genetic studies of aging correlate with observations on mutation load contribution to limiting/ shortening the lifespan [78, 79]. Additionally, there are evidences that inhibiting chromosome instability might underlie successful anti-aging strategies [80]. Thus, genetic instability at chromosomal level involved in human aging and/or lifespan shortening is an intriguing target for lifespan-extension and antiaging interventions.

Genetic-environmental interactions play an important role in generating chromosome instability and, probably, somatic chromosomal mosaicism [12, 13, 44]. It is highly likely that environmental triggers are able to stimulate or to inhibit genome/chromosome instability [7, 12, 13]. Here, it is to mention that a cellular genome may demonstrate a kind of a selfcorrection resulting in a corrected/normal genomes in daughter cells $[14,15,17,18]$. Consequently, one can suggest the cellular genome has high self-correctional potential. Alternatively, somatic mosaicism is able to be a stress response or cellular adaptation to adverse environmental effects [13, 40]. Moreover, actual technologies of in vivo correction of cellular genomes have the intrinsic potential for becoming more safe and efficient in forthcoming future [16, 80]. Therefore, either special genome editing technologies (e.g. CRISPR/Cas9-mediated methods) or stimulated genetic-environmental interactions (i.e. medication, life style, diet, (anti-)stress etc.) are able to decrease levels of chromosomal mosaicism/instability. According to our hypothesis, these opportunities might be used for decreasing the risks for complex diseases/ conditions, improving the dynamics of genetic diseases caused by mosaicism, increasing the lifespan, and rejuvenating. Disease progression in cancers and neurodegenerative diseases is able to be slowed down by therapeutic interventions decreasing the levels of chromosomal mosaicism/instability. Similarly, such interventions could decrease the risk for complex diseases, cancer, reproductive and behavioral problems. Figure 1 illustrates schematically the outcome of such interventions.

In the postgenomic era, cytogenomic/cytogenetic analysis is required to uncover complemented molecular and cellular pathways to a disease and therapeutic interventions. Chromosome-oriented postgenomic studies are able to provide new understanding how genomic variations produce the phenotype at saupramolecular or nuclear level and what can be done to diminish the effect of causative mutations. The latter may be achieved by either correcting the pathways altered by chromosome abnormalities/instability or decreasing the number of cells carrying the mutations [81-84]. Since cancers are one of the most intriguing models for somatic mutagenesis, a number of the theoretical and empirical (oncocytogenetic) observations may contribute to our hypothesis. Taking into account that both clonal and nonclonal chromosomal aberrations (mosaic chromosome aberrations) are involved in cancers, changes in mosaicism rates for decreasing cancer risks (as suggested in Fig. 1.3) might be complicated [84, 85]. Depending on cancer phase, specific strategies for decreasing mosacism rates are to be developed. Furthermore, mosaicism has recently been suggested to be beneficial in some cancer cell populations ("trade-off" of cellular adaptation) [86]. In this instance, there is a need to develop approaches to differ between "beneficial" and "nonbeneficial" mosaicism in cancers. In general, it is to conclude that therapeutic strategies to manage mosaicism rates should be personalized.

The results of studying the dynamic nature of somatic mosaicism and genetic-environmental interactions are relevant to a wide spectrum of biomedical fields 


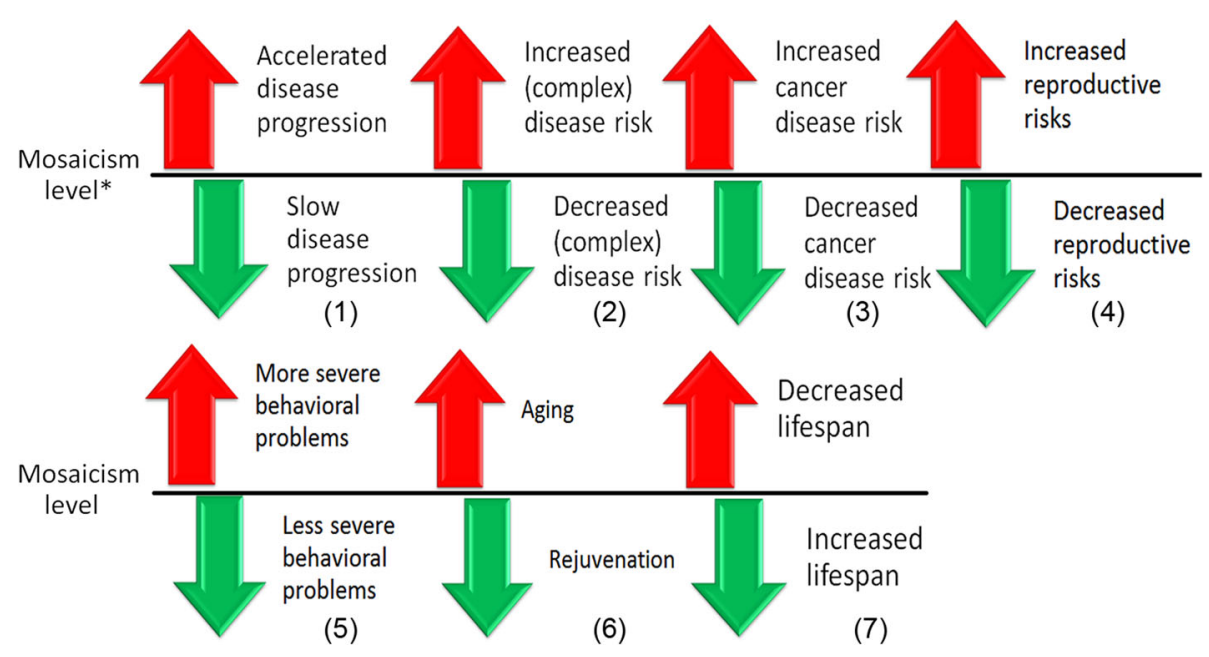

Fig. 1 Biomedical issues of the hypothesis. When mosaicism is detected, therapeutic interventions might be applied to decrease the level of the mosaicism (green arrows). Otherwise, the level of mosaicism is more likely to increase (red arrows) through the interaction of unstable cellular genomes with the environment. Thus, a disease associated with somatic (chromosomal) mosaicism would exhibit accelerated progression without the interventions (i.e. the increase of mosaicism level) in contrast to slow progression resulted from therapeutic interventions aimed at the decrease in mosaicism level (1). Somatic mosaicism may be an important element of pathogenic cascade in complex diseases; the increase of mosaicism level is likely to increase the risk for these diseases, whereas the decrease of mosaicism level is likely to decrease the risk for these diseases (2). Similarly, the risk of cancer (3) and reproductive risks (4) might correlate with changing of mosaicism levels. According to a previous cytogenomic hypothesis [68], the severity of behavioral problems is able to be modulated by changing in levels of somatic mosaicism as depicted in (5). Since aging is mediated by the accumulation of somatic mutation (i.e. the increase of mosaicism level) [63, 69-74], it is highly likely that therapeutic interventions aimed at the decrease of mosaicism level might cause rejuvenation (6). Finally, taking into account (1-6), we hypothesize that the increase of mosaicism level is associated with decreased lifespan whereas the interventions aimed at the decrease of mosaicism level might increase the lifespan. * - mosaicism level detected in an individual during molecular (cytogenetic) analysis

(Fig. 1). The development of efficient procedures providing the decrease in levels of somatic genetic instability (chromosomal mosaicism/instability) would certainly be a breakthrough in modern biomedical science. To this end, it appears that our hypothesis is applicable to all the types of somatic mosaicism.

\section{Acknowledgments}

Our communication is dedicated to Dr. llia V. Soloviev.

\section{Authors' contributions}

All authors developed the hypothesis. IYI wrote the manuscript. All authors have read and approved the final manuscript.

\section{Funding}

The research of professors SG Vorsanova and IY lourov is partially funded by RFBR and CITMA according to the research project No. 18-515-34005. Prof. SG Vorsanova is supported by the Government Assignment of the Russian Ministry of Health, Assignment no. AAAA-A18-118051590122-7. Prof. IY lourov is supported by the Government Assignment of the Russian Ministry of Science and Higher Education, Assignment no. AAAA-A19-119040490101-6.

\section{Availability of data and materials}

not applicable.

\section{Ethics approval and consent to participate}

not applicable.

\section{Consent for publication}

not applicable.

\section{Competing interests}

The authors declare that they have no competing interests.

\section{Author details}

${ }^{1}$ Veltischev Research and Clinical Institute for Pediatrics of the Pirogov Russian National Research Medical University, Ministry of Health of Russian Federation, 125412 Moscow, Russia. ${ }^{2}$ Mental Health Research Center, 117152 Moscow, Russia. ${ }^{3}$ Department of Medical Biological Disciplines, Belgorod State University, 308015 Belgorod, Russia.

Received: 4 March 2020 Accepted: 24 April 2020

Published online: 07 May 2020

\section{References}

1. Hall JG. Review and hypotheses: somatic mosaicism: observations related to clinical genetics. Am J Hum Genet. 1988;43(4):355-63.

2. Gottlieb B, Beitel LK, Trifiro MA. Somatic mosaicism and variable expressivity. Trends Genet. 2001;17(2):79-82.

3. lourov IY, Vorsanova SG, Yurov YB. Chromosomal mosaicism goes global. Mol Cytogenet. 2008; 1:26.

4. Iourov IY, Vorsanova SG, Yurov YB. Somatic genome variations in health and disease. Curr Genomics. 2010;11(6):387-96.

5. Biesecker $L G$, Spinner NB. A genomic view of mosaicism and human disease. Nat Rev Genet. 2013;14(5):307-20.

6. Campbell IM, Shaw CA, Stankiewicz P, Lupski JR. Somatic mosaicism: implications for disease and transmission genetics. Trends Genet. 2015;31(7): 382-92.

7. Iourov IY, Vorsanova SG, Yurov YB, Kutsev SI. Ontogenetic and pathogenetic views on somatic chromosomal mosaicism. Genes (Basel). 2019;10(5):E379.

8. Jacobs PA, Court Brown WM, Doll R. Distribution of human chromosome counts in relation to age. Nature. 1961;191:1178-80.

9. Robberecht C, Vanneste E, Pexsters A, D'Hooghe T, Voet T, Vermeesch JR. Somatic genomic variations in early human prenatal development. Curr Genomics. 2010;11(6):397-401. 
10. Yurov YB, Vorsanova SG, lourov IY. Ontogenetic variation of the human genome. Curr Genomics. 2010;11(6):420-5.

11. Zhang L, Dong X, Lee M, Maslov AY, Wang T, Vijg J. Single-cell wholegenome sequencing reveals the functional landscape of somatic mutations in B lymphocytes across the human lifespan. Proc Natl Acad Sci U S A. 2019; 116(18):9014-9.

12. Lourov IY, Vorsanova SG, Yurov YB. Somatic cell genomics of brain disorders: a new opportunity to clarify genetic-environmental interactions. Cytogenet Genome Res. 2013;139(3):181-8.

13. Heng HH, Regan S, Christine JY. Genotype, environment, and evolutionary mechanism of diseases. Environ Dis. 2016:1 (1):14-23.

14. Hirschhorn R. In vivo reversion to normal of inherited mutations in humans. J Med Genet. 2003;40(10):721-8.

15. Davis BR, Candotti F. Genetics. Mosaicism - switch or spectrum? Science. 2010:330(6000):46-7.

16. Mehravar M, Shirazi A, Nazari M, Banan M. Mosaicism in CRISPR/Cas9mediated genome editing. Dev Biol. 2019;445(2):156-62.

17. Li LB, Chang KH, Wang PR, Hirata RK, Papayannopoulou T, Russell DW. Trisomy correction in Down syndrome induced pluripotent stem cells. Cell Stem Cell. 2012;11(5):615-9.

18. Bazrgar M, Gourabi H, Valojerdi MR, Yazdi PE, Baharvand H. Self-correction of chromosomal abnormalities in human preimplantation embryos and embryonic stem cells. Stem Cells Dev. 2013;22(17):2449-56.

19. Bolton H, Graham SJL, Van der Aa N, Kumar P, Theunis K, Fernandez Gallardo E, Voet T, Zernicka-Goetz M. Mouse model of chromosome mosaicism reveals lineage-specific depletion of aneuploid cells and normal developmental potential. Nat Commun. 2016;7:11165.

20. Schinzel A. Catalogue of unbalanced chromosome aberrations in man: Walter de Gruyter; 2001.

21. Lourov IY, Vorsanova SG, Yurov YB. Chromosomal variation in mammalian neuronal cells: known facts and attractive hypotheses. Int Rev Cytol. 2006; 249:143-91.

22. Liehr T, Al-Rikabi A. Mosaicism: reason for normal phenotypes in carriers of small supernumerary marker chromosomes with known adverse outcome. Syst Rev Front Genet. 2019;10:1131.

23. Liehr $T$, Liehr $L B$. An update on small supernumerary marker chromosomes (sSMC). Res Results Biomedicine. 2019;5(2):4-6.

24. Hassold T, Hunt P. To err (meiotically) is human: the genesis of human aneuploidy. Nat Rev Genet. 2001;2(4):280-91.

25. Iourov IY, Vorsanova SG, Yurov YB. Intercellular genomic (chromosomal) variations resulting in somatic mosaicism: mechanisms and consequences. Curr Genomics. 2006;7(7):435-46.

26. Campbell IM, Stewart JR, James RA, Lupski JR, Stankiewicz P, Olofsson P, Shaw CA. Parent of origin, mosaicism, and recurrence risk: probabilistic modeling explains the broken symmetry of transmission genetics. Am J Hum Genet. 2014;95(4):345-59.

27. Graham EJ, Vermeulen $M$, Vardarajan B, Bennett D, De Jager P, Pearse RV 2nd, Young-Pearse TL, Mostafavi S. Somatic mosaicism of sex chromosomes in the blood and brain. Brain Res. 2019:1721:146345.

28. Vorsanova SG, Yurov YB, Soloviev IV, lourov IY. Molecular cytogenetic diagnosis and somatic genome variations. Curr Genomics. 2010;11(6):440-6.

29. Rohrback S, Siddoway B, Liu CS, Chun J. Genomic mosaicism in the developing and adult brain. Dev Neurobiol. 2018;78(11):1026-48.

30. Vanneste E, Voet T, Le Caignec C, Ampe M, Konings P, Melotte C, Debrock S, Amyere M, Vikkula M, Schuit F, Fryns JP, Verbeke G, D'Hooghe T, Moreau $Y$, Vermeesch JR. Chromosome instability is common in human cleavagestage embryos. Nat Med. 2009;15(5):577-83 s.

31. Kalousek DK, Vekemans M. Confined placental mosaicism. J Med Genet. 1996:33(7):529-33.

32. Weier JF, Weier HU, Jung CJ, Gormley M, Zhou Y, Chu LW, Genbacev O, Wright AA, Fisher SJ. Human cytotrophoblasts acquire aneuploidies as they differentiate to an invasive phenotype. Dev Biol. 2005;279(2): $420-32$

33. Yurov YB, lourov IY, Monakhov W, Soloviev IV, Vostrikov VM, Vorsanova SG The variation of aneuploidy frequency in the developing and adult human brain revealed by an interphase FISH study. J Histochem Cytochem. 2005: 53(3):385-90.

34. Yurov YB, lourov IY, Vorsanova SG, Liehr T, Kolotii AD, Kutsev SI, Pellestor F, Beresheva AK, Demidova IA, Kravets VS, Monakhov W, Soloviev IV. Aneuploidy and confined chromosomal mosaicism in the developing human brain. PLoS One. 2007;2(6):e558.
35. Taylor TH, Gitlin SA, Patrick JL, Crain JL, Wilson JM, Griffin DK. The origin, mechanisms, incidence and clinical consequences of chromosomal mosaicism in humans. Hum Reprod Update. 2014;20(4):571-81.

36. Daughtry BL, Chavez SL. Chromosomal instability in mammalian preimplantation embryos: potential causes, detection methods, and clinical consequences. Cell Tissue Res. 2016;363(1):201-25.

37. Vorsanova SG, Kolotii AD, lourov IY, Monakhov W, Kirillova EA, Soloviev IV, Yurov YB. Evidence for high frequency of chromosomal mosaicism in spontaneous abortions revealed by interphase FISH analysis. J Histochem Cytochem. 2005;53(3):375-80

38. Vorsanova SG, lourov IY, Kolotii AD, Beresheva AK, Demidova IA, Kurinnaia OS, Kravets VS, Monakhov W, Soloviev IV, Yurov YB. Chromosomal mosaicism in spontaneous abortions: analysis of 650 cases. Russ J Genet. 2010;46(10):1197-200.

39. van den Berg MM, van Maarle MC, van Wely M, Goddijn M. Genetics of early miscarriage. Biochim Biophys Acta. 2012;1822(12):1951-9.

40. Horne SD, Chowdhury SK, Heng HH. Stress, genomic adaptation, and the evolutionary trade-off. Front Genet. 2014;5:92.

41. Arendt T, Mosch B, Morawski M. Neuronal aneuploidy in health and disease: a cytomic approach to understand the molecular individuality of neurons. Int J Mol Sci. 2009:10(4):1609-27.

42. Bushman DM, Chun J. The genomically mosaic brain: aneuploidy and more in neural diversity and disease. Semin Cell Dev Biol. 2013;24(4):357-69.

43. Lourov IY, Vorsanova SG, Yurov YB. Single cell genomics of the brain: focus on neuronal diversity and neuropsychiatric diseases. Curr Genomics. 2012; 13(6):477-88

44. Yurov YB, Vorsanova SG, lourov IY. Chromosome instability in the neurodegenerating brain. Front Genet. 2019;10:892.

45. Potter H, Chial HJ, Caneus J, Elos M, Elder N, Borysov S, Granic A. Chromosome instability and mosaic aneuploidy in neurodegenerative and neurodevelopmental disorders. Front Genet. 2019;10:1092.

46. Yurov YB, Vorsanova SG, lourov IY, Demidova IA, Beresheva AK, Kravetz VS, Monakhov W, Kolotii AD, Voinova-Ulas VY, Gorbachevskaya NL. Unexplained autism is frequently associated with low-level mosaic aneuploidy. J Med Genet. 2007;44(8):521-5.

47. Hochstenbach R, Buizer-Voskamp JE, Vorstman JA, Ophoff RA. Genome arrays for the detection of copy number variations in idiopathic mental retardation, idiopathic generalized epilepsy and neuropsychiatric disorders: lessons for diagnostic workflow and research. Cytogenet Genome Res. 2011; 135(3-4):174-202.

48. Yurov YB, Vostrikov VM, Vorsanova SG, Monakhov W, lourov IY. Multicolor fluorescent in situ hybridization on post-mortem brain in schizophrenia as an approach for identification of low-level chromosomal aneuploidy in neuropsychiatric diseases. Brain and Development. 2001;23(Suppl 1):S186-90.

49. Yurov YB, lourov IY, Vorsanova SG, Demidova IA, Kravetz VS, Beresheva AK, Kolotii AD, Monakchov W, Uranova NA, Vostrikov VM, Soloviev IV, Liehr T. The schizophrenia brain exhibits low-level aneuploidy involving chromosome 1. Schizophr Res. 2008:98(1-3):139-47.

50. Sakai M, Watanabe Y, Someya T, Araki K, Shibuya M, Niizato K, Oshima K, Kunii Y, Yabe H, Matsumoto J, Wada A, Hino M, Hashimoto T, Hishimoto A, Kitamura N, Iritani S, Shirakawa O, Maeda K, Miyashita A, Niwa S, Takahashi H, Kakita A, Kuwano R, Nawa H. Assessment of copy number variations in the brain genome of schizophrenia patients. Mol Cytogenet. 2015;8:46.

51. Yurov YB, Vorsanova SG, Demidova IA, Kravets VS, Vostrikov VM, Soloviev IV, Uranova NA, lourov IY. Genomic instability in the brain: chromosomal mosaicism in schizophrenia. Zh Nevrol Psikhiatr Im S S Korsakova. 2016; 116(11):86-91.

52. Yurov YB, Vorsanova SG, Demidova IA, Kolotii AD, Soloviev IV, lourov IY. Mosaic brain aneuploidy in mental illnesses: an association of low-level post-zygotic aneuploidy with schizophrenia and comorbid psychiatric disorders. Curr Genomics. 2018;19(3):163-72.

53. Iourov IY, Vorsanova SG, Liehr T, Kolotii AD, Yurov YB. Increased chromosome instability dramatically disrupts neural genome integrity and mediates cerebellar degeneration in the ataxia-telangiectasia brain. Hum Mol Genet. 2009;18(14):2656-69.

54. Leija-Salazar M, Piette C, Proukakis C. Review: somatic mutations in neurodegeneration. Neuropathol Appl Neurobiol. 2018;44(3):267-85.

55. Shepherd CE, Yang Y, Halliday GM. Region- and cell-specific aneuploidy in brain aging and neurodegeneration. Neuroscience. 2018;374:326-34. 
56. Mosch B, Morawski M, Mittag A, Lenz D, Tarnok A, Arendt T. Aneuploidy and DNA replication in the normal human brain and Alzheimer's disease. Neurosci. 2007;27(26):6859-67.

57. lourov IY, Vorsanova SG, Liehr T, Yurov YB. Aneuploidy in the normal, Alzheimer's disease and ataxia-telangiectasia brain: differential expression and pathological meaning. Neurobiol Dis. 2009;34(2):212-20.

58. Arendt T, Brückner MK, Mosch B, Lösche A. Selective cell death of hyperploid neurons in Alzheimer's disease. Am J Pathol. 2010;177(1):15-20.

59. lourov IY, Vorsanova SG, Yurov YB. Genomic landscape of the Alzheimer's disease brain: chromosome instability — aneuploidy, but not tetraploidy —mediates neurodegeneration. Neurodegener Dis. 2011;8(1-2):35-7.

60. Migliore L, Coppedè F, Fenech M, Thomas P. Association of micronucleus frequency with neurodegenerative diseases. Mutagenesis. 2011;26(1):85-92.

61. Yurov YB, Vorsanova SG, lourov IY. The DNA replication stress hypothesis of Alzheimer's disease. ScientificWorldJournal. 2011;11:2602-12.

62. Arendt T, Brückner MK, Lösche A. Regional mosaic genomic heterogeneity in the elderly and in Alzheimer's disease as a correlate of neuronal vulnerability. Acta Neuropathol. 2015;130(4):501-10.

63. Kennedy SR, Loeb LA, Herr AJ. Somatic mutations in aging, cancer and neurodegeneration. Mech Ageing Dev. 2012;133(4):118-26.

64. Yurov YB, Vorsanova SG, Liehr T, Kolotii AD, lourov IY. X chromosome aneuploidy in the Alzheimer's disease brain. Mol Cytogenet. 2014;7:20.

65. Hou Y, Song H, Croteau DL, Akbari M, Bohr VA. Genome instability in Alzheimer disease. Mech Ageing Dev. 2017;161(Pt A):83-94.

66. Yurov YB, Vorsanova SG, lourov IY. Human molecular neurocytogenetics. Curr Genet Med Rep. 2018;6(4):155-64.

67. Liu G, Ye CJ, Chowdhury SK, Abdallah BY, Horne SD, Nichols D, Heng HH. Detecting chromosome condensation defects in gulf war illness patients. Curr Genomics. 2018;19(3):200-6.

68. Vorsanova SG, Zelenova MA, Yurov YB, lourov IY. Behavioral variability and somatic mosaicism: a cytogenomic hypothesis. Curr Genomics. 2018;19(3): 158-62.

69. Maslov AY, Vijg J. Genome instability, cancer and aging. Biochim Biophys Acta. 2009;1790(10):963-9.

70. Yurov YB, Vorsanova SG, lourov IY. GIN'n'CIN hypothesis of brain aging: deciphering the role of somatic genetic instabilities and neural aneuploidy during ontogeny. Mol Cytogenet. 2009;2:23.

71. Schumacher B, Vijg J. Age is in the nucleus. Nat Metab. 2019;1(10):931-2.

72. Risques RA, Kennedy SR. Aging and the rise of somatic cancer-associated mutations in normal tissues. PLoS Genet. 2018;14(1):e1007108.

73. Heng HH. Genome Chaos. Cambridge: Academic Press; 2019.

74. Machiela MJ. Mosaicism, aging and cancer. Curr Opin Oncol. 2019;31(2):108-13.

75. Iourov IY, Liehr T, Vorsanova SG, Mendez-Rosado LA, Yurov YB. The applicability of interphase chromosome-specific multicolor banding (ICSMCB) for studying neurodevelopmental and neurodegenerative disorders. Res Results Biomedicine. 2019:5(3):4-9.

76. Simonetti G, Bruno S, Padella A, Tenti E, Martinelli G. Aneuploidy: cancer strength or vulnerability? Int J Cancer. 2019;144(1):8-25.

77. Ben-David U, Amon A. Context is everything: aneuploidy in cancer. Nat Rev Genet. 2020:21:44-62.

78. Cui R, Medeiros T, Willemsen D, lasi LNM, Collier GE, Graef M, Reichard M, Valenzano DR. Relaxed selection limits lifespan by increasing mutation load. Cell. 2019;178(2):385-99 e20.

79. Toyama BH, Arrojo E, Drigo R, Lev-Ram V, Ramachandra R, Deerinck TJ, Lechene C, Ellisman MH, Hetzer MW. Visualization of long-lived proteins reveals age mosaicism within nuclei of postmitotic cells. J Cell Biol. 2019;218(2):433-44

80. Barroso-Vilares M, Logarinho E. Chromosomal instability and proinflammatory response in aging. Mech Ageing Dev. 2019;182:111118.

81. Lourov IY. Cytopostgenomics: what is it and how does it work? Curr Genomics. 2019;20(2):77-8.

82. Iourov IY, Vorsanova SG, Yurov YB. The variome concept: focus on CNVariome. Mol Cytogenet. 2019;12:52.

83. Liehr T. From human cytogenetics to human chromosomics. Int J Mol Sci. 2019;20:E826.

84. Ye CJ, Stilgenbauer L, Moy A, Liu G, Heng HH. What is karyotype coding and why is genomic topology important for cancer and evolution? Front Genet. 2019;10:1082.

85. Salmina K, Huna A, Kalejs M, Pjanova D, Scherthan H, Cragg MS, Erenpreisa J. The cancer aneuploidy paradox: in the light of evolution. Genes (Basel). 2019;10(2):E83.
86. Ye CJ, Chen J, Liu G, Heng HH. Somatic genomic mosaicism in multiple myeloma. Front Genet. 2020. https://doi.org/10.3389/fgene.2020.00388.

\section{Publisher's Note}

Springer Nature remains neutral with regard to jurisdictional claims in published maps and institutional affiliations.
Ready to submit your research? Choose BMC and benefit from:

- fast, convenient online submission

- thorough peer review by experienced researchers in your field

- rapid publication on acceptance

- support for research data, including large and complex data types

- gold Open Access which fosters wider collaboration and increased citations

- maximum visibility for your research: over $100 \mathrm{M}$ website views per year

At $\mathrm{BMC}$, research is always in progress.

Learn more biomedcentral.com/submissions 